\title{
Epidemiology of respiratory syncytial virus infections in Chennai, south India
}

\author{
Anusha Hindupur, Thangam Menon*, Prabu Dhandapani \\ Department of Microbiology, $\operatorname{Dr}$ A L M Post Graduate Institute of Basic Medical Sciences, University of Madras, Taramani, Chennai, 600113, India
}

\section{Introduction}

Respiratory syncytial virus (RSV) is a major cause of mortality and morbidity among children ${ }^{1}$ and the elderly. ${ }^{2}$ It causes mild upper respiratory tract infections to severe life threatening lower respiratory tract infections like bronchiolitis and pneumonia. Based on variations in the glycoprotein gene, RSV exists as two major antigenic subgroups RSV A and RSV B. RSV A is known to cause infections of greater severity than RSV B. ${ }^{3}$ Depending upon the climatic conditions and region, one subtype dominates the other.

The epidemiology of RSV shows various patterns. In tropical regions, RSV outbreaks occur in the rainy months, ${ }^{4}$ while in temperate countries it occurs during the winter months. ${ }^{5}$ Epidemiological studies are crucial to understanding regional pattern of RSV infections. Meteorological factors such as temperature, humidity and rainfall influence the severity of RSV disease in infants. ${ }^{6}$

Diagnosis of RSV infections is accomplished by several methods including viral culture, serology, antigen detection tests and nucleic acid amplification tests (NAATs). Viral culture is said to be the gold standard; however it is cumbersome, requires expertise, and has a long turnaround time. NAATs are now being used widely. Conventional PCR and nested PCR are considered to be simple and economic for any laboratory setting. However the diagnostic accuracy of these techniques is discrepant.

Hence this study was intended to determine the prevalence of RSV in respiratory specimens from children and adults. The incidence of RSV was correlated with factors such as gender, clinical presentation and meteorological conditions like monthly mean maximum and minimum temperature, average relative humidity and total monthly rainfall to understand its epidemiology. We also assessed the performance of nested RT-PCR in comparison with real time RT-PCR in the detection of RSV A and B to analyse the application of nRT-PCR in resource limited settings for surveillance and diagnosis.

\section{Materials and methods}

\subsection{Collection of specimen and transportation}

We conducted a prospective pilot study over a 1 year period from April 2016-April 2017. A total of one hundred and forty six nasal swabs were collected from patients (majorly children) with symptoms of acute respiratory infection (ARI). This study was approved by the institutional human ethical committee. Informed consent was obtained from the parents of all the children and individual participants included in the study. Nasal swabs were collected using sterile flocked nylon swabs, by placing them $2-3 \mathrm{~cm}$ deep inside the nostril and rotating 2-3 times. The swabs were immediately placed in sterile viral transport medium (HiViral transport Kit, Himedia, Mumbai) and transported to laboratory on ice. An aliquot of the sample was stored at $-80{ }^{\circ} \mathrm{C}$ for further investigations. Demographic and clinical details such as age, sex, clinical symptoms, clinical diagnosis and duration of symptoms were collected using well-structured questionnaire.

\subsection{RNA extraction and reverse transcription}

RNA was extracted from these samples using NucleoSpin RNA virus kit (Macherey-Nagel, Germany) according to manufacturer's instructions. The extracted RNA was immediately subjected to reverse transcription and the remaining RNA was stored at $-80^{\circ} \mathrm{C}$. The reaction mixture for reverse transcription consisted of $4 \mu \mathrm{l}$ of $5 \mathrm{X}$ M-MuLV reverse transcriptase buffers, $1 \mu \mathrm{l}$ of $0.4 \mu \mathrm{g} / \mu \mathrm{l}$ random hexamer, $2 \mu \mathrm{l}$ of $10 \mathrm{mM}$ dNTPs, 40U of M-MuLV reverse transcriptase, $8 \mathrm{U}$ of RNase inhibitor, $5 \mu$ l of RNA template. The volume was made up to $20 \mu \mathrm{l}$ with RNase free water. The reaction was carried out for one cycle at $37^{\circ} \mathrm{C}$ for one hour followed by $93{ }^{\circ} \mathrm{C}$ for 5 min cDNA was stored at $-20^{\circ} \mathrm{C}$ until use.

\subsection{Detection of subtypes of RSV by real time RT-PCR}

Real time RT-PCR was applied to all the samples using Taqman probes specific for RSV A and B (Table 1). Simplex real time RT-PCR was performed using our optimized cycling parameters. Each $10 \mu \mathrm{l}$

\footnotetext{
* Corresponding author.

E-mail address: thangam56@gmail.com (T. Menon).
} 
Table 1

Details of primers and probes used.

\begin{tabular}{|c|c|c|}
\hline Nested RT-PCR & & References \\
\hline \multicolumn{3}{|l|}{ I round primers } \\
\hline RSV-A-OF2 & CAGCTCCGTTATCACATCTCTAGGAGCC & 7 \\
\hline RSV-A-OR2 & TGGGTTGTCTATGAGCAGATAKKAAACCA & \\
\hline RSV-B-OF2 & CGGGCCAGAAGAGAAGCACCACAGTA & \\
\hline $\begin{array}{l}\text { RSV-B-OR2 } \\
\text { II round primers }\end{array}$ & TGATCCTTCTTTGATGTTGGTGGTGC & \\
\hline RSVA-IF2 & TGACCCATTAGTGTTCCCCTCTGAT GAAT & \\
\hline RSVA-IR2 & CTTCTGGCCTTRCAGTATARGAG CAGT & \\
\hline RSV-B-IF1 & GTCGCATCTCCAACATTGRAAC & \\
\hline RSV-B-IR1 & TGGTGCATAGAGGTGATGTGTG & \\
\hline Real time RT-PCR & & 8 \\
\hline \multicolumn{3}{|l|}{ RSVA } \\
\hline $\begin{array}{l}\text { RS-F1 Forward } \\
\text { primer }\end{array}$ & AACAGATGTAAGCAGCTCCGTTATC & \\
\hline $\begin{array}{l}\text { RS-F2 Reverse } \\
\text { primer }\end{array}$ & CGATTTTTATTGGATGCTGTACATTT & \\
\hline RS-F3 Probe & TGCCATAGCATGACACAATGGCTCCT & \\
\hline RSVB & & 9 \\
\hline Sense & AACAGACATAAGCAGCTCAGTAATT & \\
\hline antisense & CGATTTTTGTTGGATGCAGTGCATTT & \\
\hline Probe & CTAGGAGCTATAGTGTCATGCTATGGT & This study \\
\hline
\end{tabular}

reaction mixture contained $5 \mu \mathrm{l}$ of $5 \mathrm{X}$ FastStart Universal Probe Master (Rox), 5 pmol each of forward and reverse primers, 2 pmol of probe, $2 \mu \mathrm{l}$ of cDNA and $2.4 \mu \mathrm{l}$ of nuclease free water. The cycling conditions were $95^{\circ} \mathrm{C}$ for $10 \mathrm{~min}, 45$ cycles of $95^{\circ} \mathrm{C}$ for $15 \mathrm{~s}$ and $60^{\circ} \mathrm{C}$ for $1 \mathrm{~min}$ followed by $72^{\circ}$ for $10 \mathrm{~s}$. An annealing temperature of $56^{\circ} \mathrm{C}$ for $1 \mathrm{~min}$ was used for RSV B. Positive and negative controls were included in each run. The amplified nucleic acids were detected with the StepOnePlus Real-Time PCR System (Applied Biosystems, USA). The samples were interpreted as positive and negative based on their threshold cycles $\left(\mathrm{C}_{\mathrm{t}}\right.$ value).

\subsection{Nested RT-PCR}

Multiplex nested RT-PCR (nRT-PCR) was also performed using primer pairs targeting the fusion gene of RSV A and RSV B (Table 1). In the first round, the PCR reaction mixture consisted of $2 \mu$ of $10 \mathrm{X}$ Taq buffer, $0.5 \mu \mathrm{l}$ of $10 \mathrm{mM}$ dNTPs, $1 \mathrm{U}$ of Taq polymerase, 5 pmol of each primer (2 sets of forward and reverse primers specific for RSV A and RSV B) and $2 \mu \mathrm{l}$ of cDNA. The volume was adjusted to $20 \mu \mathrm{l}$ using sterile nuclease free water. $1 \mu \mathrm{l}$ of the first round product was used as the template in the second round. The reaction mixture for the second round was same as that of first round. The first round reaction was set up at an initial denaturation at $94^{\circ} \mathrm{C}$ for $5 \mathrm{~min}$, followed by 35 cycles of denaturation at $94^{\circ} \mathrm{C}$ for $30 \mathrm{~s}$, annealing at $60^{\circ} \mathrm{C}$ for $30 \mathrm{~s}$, extension at $72^{\circ} \mathrm{C}$ for $30 \mathrm{~s}$ and a final extension of $10 \mathrm{~min}$ at $72^{\circ} \mathrm{C}$. The cycling parameters were same for second round PCR except that 20 cycles were used instead of 35 cycles. Positive and negative controls were included in each run. PCR products were analyzed by electrophoresis with $1.5 \%$ agarose gel in $1 \mathrm{X}$ Tris- Borate- Ethylenediaminetetra acetic acid (TBE) buffer. PCR products were visualized using the Gel documentation system.

\subsection{Statistical analysis}

Data comparison based on gender and clinical presentation was analyzed using chi-square test. Descriptive statistics was used for continuous variables. The correlation between meteorological factors and incidence of RSV was assessed using Pearson's correlation coefficient and p-values less than 0.05 were considered as significant. Sensitivity, specificity, positive predictive value (PPV), negative predictive value (NPV) and negative likelihood ratio (NLR) were calculated to determine the diagnostic performance of nested RT-PCR. The data obtained from
Table 2

Demographic details and clinical presentations of RSV positive and negative patients.

\begin{tabular}{|c|c|c|c|}
\hline Characteristics & $\begin{array}{l}\text { Total } \\
(n=146)\end{array}$ & $\begin{array}{l}\text { RSV positives } \\
(\mathrm{n}=32)(22 \%)\end{array}$ & $\begin{array}{l}\text { RSV negatives } \\
(\mathrm{n}=114)(78 \%)\end{array}$ \\
\hline \multicolumn{4}{|l|}{ Gender (n) (\%) } \\
\hline Male & $75(51.4)$ & $16(50)$ & $59(51.8)$ \\
\hline Female & $71(48.6)$ & $16(50)$ & $55(48.2)$ \\
\hline \multicolumn{4}{|c|}{ Age group (n) (\%) } \\
\hline$\leq 1$ year & $32(22)$ & $3(9)$ & $29(25)$ \\
\hline $1-2$ years & $37(25)$ & $7(22)$ & $30(26)$ \\
\hline $2-3$ years & 25 (17) & 6 (19) & $19(17)$ \\
\hline $3-5$ years & $26(18)$ & $6(19)$ & $20(18)$ \\
\hline 5-7 years & $12(8)$ & $1(3)$ & $11(10)$ \\
\hline $7-15$ years & $3(2)$ & $1(3)$ & $2(1)$ \\
\hline $15-25$ years & $6(4)$ & $6(19)$ & $0(0)$ \\
\hline$>25$ years & $5(3)$ & $2(6)$ & $3(3)$ \\
\hline $\begin{array}{l}\text { Duration of } \\
\text { symptoms }\end{array}$ & $5.4 \pm 3.6$ & $4.5 \pm 2.5$ & $5.7 \pm 3.7$ \\
\hline \multicolumn{4}{|c|}{ Clinical symptoms (n) (\%) } \\
\hline Fever & $85(58)$ & $22(69)$ & $63(55)$ \\
\hline cough & $122(84)$ & $27(84)$ & $95(83)$ \\
\hline Rhinorrhea & $107(73)$ & $26(81)$ & $81(71)$ \\
\hline Myalgia & $11(8)$ & $3(9)$ & $8(7)$ \\
\hline Nasal congestion & $80(55)$ & $23(72)^{*}$ & $57(50)$ \\
\hline Sore throat & $14(10)$ & $7(22) * *$ & $7(6)$ \\
\hline Wheezing & $10(7)$ & $2(6)$ & $8(7)$ \\
\hline
\end{tabular}

Chi-square test was used to analyse the data.

${ }^{*} p=0.043$.

$* * p=0.014$.

a Duration of symptoms is represented as mean \pm SD.

both the tests were analyzed by McNemar's test. Data analysis was done using online statistical software, QuickCalcs (GraphPad Software).

\section{Results}

\subsection{Prevalence of RSV}

From April 2016 to April 2017, one hundred and forty six patients with acute respiratory infection were recruited in the study. RSV A was identified in 27/146 (18.4\%) samples and RSV B was detected in 5/146 (3.4\%) samples by real time RT-PCR. In all, 32/146 (22\%) samples were positive for RSV.

\subsection{Clinical presentation of RSV in patients}

The major clinical symptoms observed in RSV positive patients were cough $(27 / 32,84 \%)$, followed by rhinorrhea and nasal congestion (23/ $32,71.8 \%$ ) (Table 2). Statistically significant association was found between nasal congestion and presence of RSV $(p<0.05)$. One patient had a co-infection with influenza B virus (Data not shown). A male: female ratio of $1: 1$ was observed among the patients with RSV. Twenty two of the thirty two positive patients were less than 5 years old (Table 2).

\subsection{Correlation between incidence of RSV and meteorological factors}

The incidence of RSV was highest during the months of November to February (Fig. 1). The total number of RSV positives correlated with mean monthly maximum temperature, mean monthly minimum temperature (Fig. 2) and average relative humidity (Fig. 3). There was no statistically significant association between RSV incidence and total rainfall (Fig. 3) (Table 3).

\subsection{Comparison between real time RT-PCR and nRT-PCR}

Of the 27 RSV A detected by real time RT-PCR, only two samples 


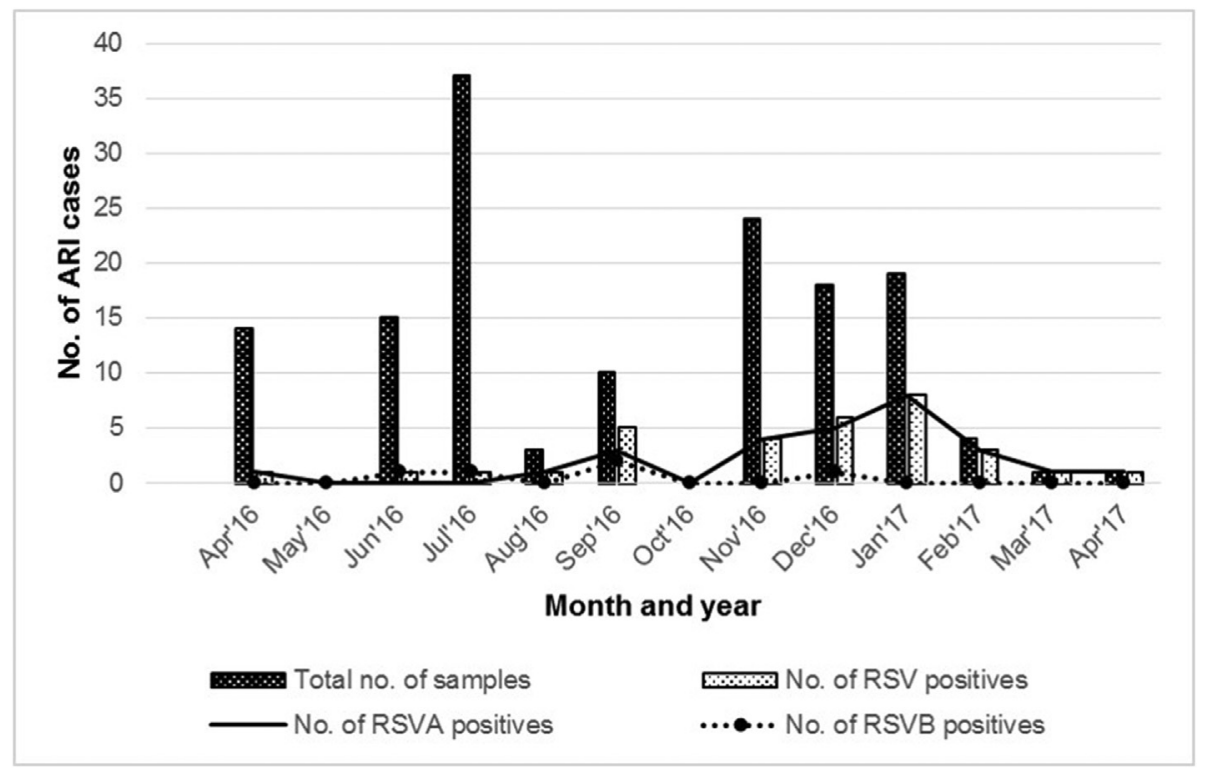

Fig. 1. Seasonal varisations in the incidence of RSV infections.

were positive for RSV A by nRT-PCR. However, all the five RSV B positives were also detected by nRT-PCR. Totally real time RT-PCR detected thirty two positives, while nRT-PCR detected only seven out of 146 samples $(4.7 \%, p<0.0001)$. The overall agreement between real time RT-PCR and nRT-PCR was found to be $21.8 \%$ (95\% confidence interval (C.I.): $14 \%-28.6 \%$ ). With respect to real time RT-PCR, the overall sensitivity, specificity, NPV, PPV and Negative likelihood ratio of nRT-PCR were found to be $21.9 \%, 100 \%, 82.01 \%$. $100 \%$ and 0.78 respectively (Table 4).

\section{Discussion}

RSV is one of the most common viral etiologies of lower respiratory tract infections among infants, young children and the elderly. The prevalence rate of RSV was $22 \%$ in our study, which was in agreement with previous reports in our country. Bharaj et al. ${ }^{10}$ and Singh et al. ${ }^{11}$ reported $20.3 \%$ and $21.3 \%$ respectively. In contrast, lower prevalence rates of $8.7 \%, 18.61 \%$ and $14.5 \%$ were documented in Kolkata, ${ }^{12}$
Pune $^{13}$ and Chennai ${ }^{14}$ respectively. Varying prevalence rates were documented in different parts of the world. ${ }^{15-18}$ The difference in epidemiology of RSV in the world could be due to variations in climatic conditions, environmental factors and severity of its epidemics.

RSV infection has a wide range of clinical manifestations and in our study, cough was found to be the predominant symptom followed by nasal congestion and rhinorrhea. Similar findings have been documented in China ${ }^{19}$ and Rochester. ${ }^{20}$ Others studies have reported fever and rhinorrhea as the frequently occurring symptoms. ${ }^{10,21}$

With regards to gender, male sex has been reported as a risk factor for RSV infections. ${ }^{22}$ However, both the sexes were equally infected with RSV in our study. Similar observations were made by Fall et al. ${ }^{21}$ and Koetz et al. ${ }^{23}$ Zahlan et al. ${ }^{18}$ and Liu et al. ${ }^{24}$ documented male dominance in their study.

RSV infection is known to occur in seasonal outbreaks peaking during the winter in temperate climates and rainy season in warmer climates. Likewise this study confirmed the seasonality of RSV infection with increased positivity in September and November to February.

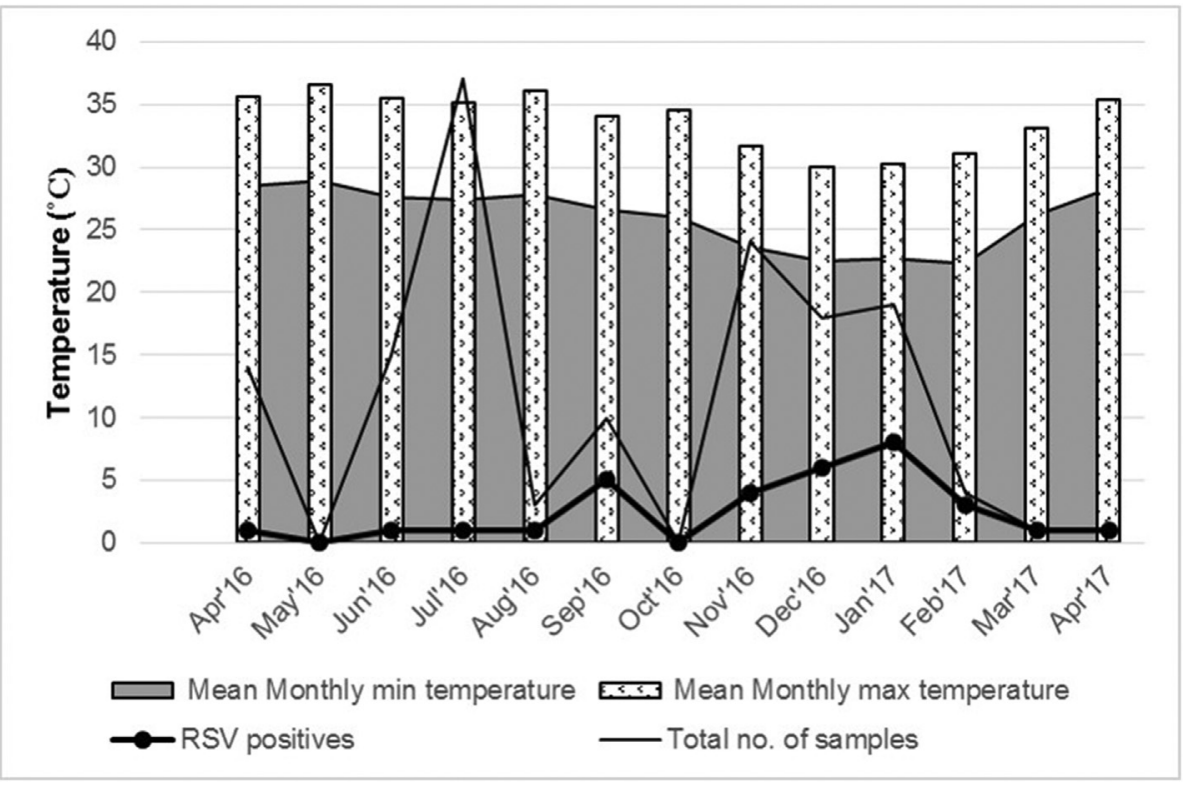

Fig. 2. Incidence of RSV in relation to temperature. 


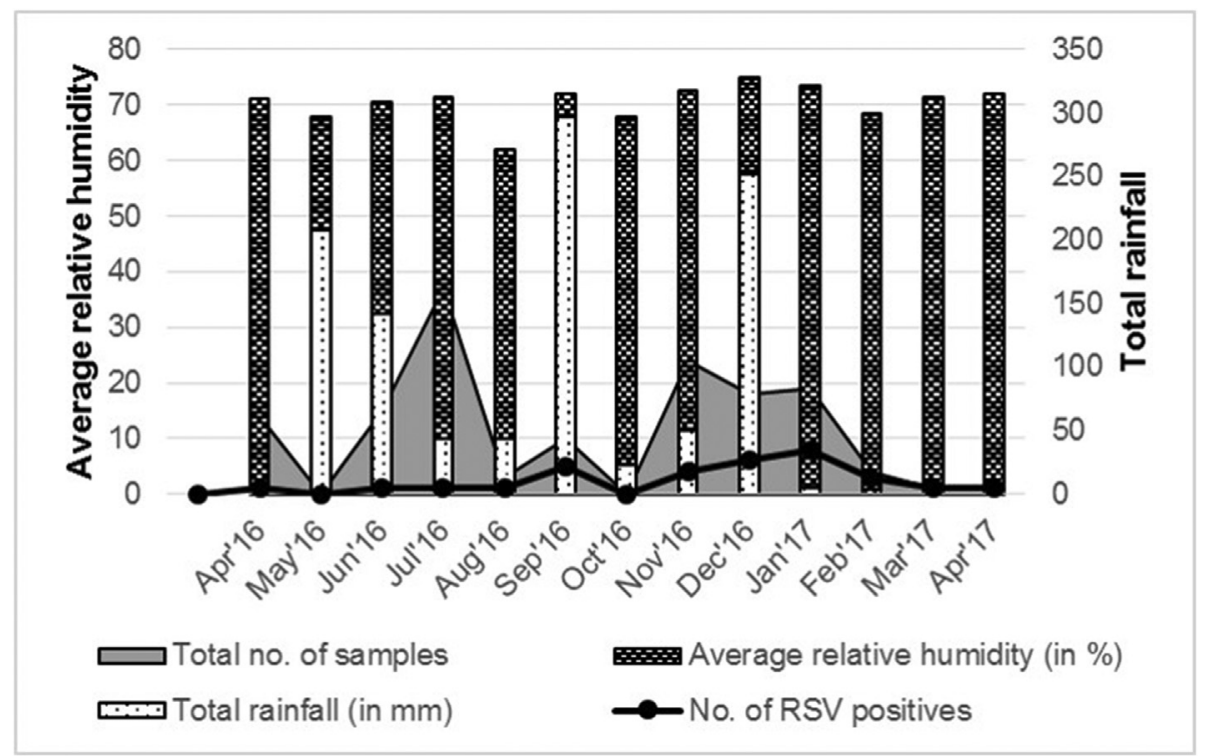

Fig. 3. Incidence of RSV in relation to average relative humidity and total rainfall.

Table 3

Correlation between incidence of RSV and meteorological factors.

\begin{tabular}{lllll}
\hline & $\begin{array}{l}\text { Mean monthly } \\
\text { maximum } \\
\text { temperature }\end{array}$ & $\begin{array}{l}\text { Mean monthly } \\
\text { minimum } \\
\text { temperature }\end{array}$ & $\begin{array}{l}\text { Total } \\
\text { rainfall }\end{array}$ & $\begin{array}{l}\text { Average } \\
\text { relative } \\
\text { humidity }\end{array}$ \\
\hline $\begin{array}{c}\text { Correlation } \\
\text { coefficient }\end{array}$ & 0.822 & 0.761 & 0.261 & 0.574 \\
$\begin{array}{c}\text { Statistical } \\
\text { significance }\end{array}$ & $p<0.001$ & $p<0.05$ & $\mathrm{NS}^{\mathrm{a}}$ & $p<0.05$ \\
\hline
\end{tabular}

${ }^{\text {a }}$ Not significant.

Similar patterns were reported by Parveen et al. ${ }^{25}$ and Choudhary et al. ${ }^{13}$ In other countries, varying seasonal distribution of RSV were reported. In Sweden, RSV detections followed a seasonal pattern, with peaks occurring in early February and lasting around 10 weeks. ${ }^{26}$ Fall et al. reported that the RSV season peaked between July and November in Senegal. ${ }^{21}$ In Central England, RSV peaked from end of November to January, similar to our study. ${ }^{27}$

Of the various meteorological factors which affect the respiratory tract, air temperature and humidity have the most marked impact. Meteorological factors lower the local resistance of the human body to infection, thereby affecting the respiratory system. ${ }^{28}$ Local resistance may deteriorate in several ways, for example, low humidity leads to loss of water vapor from the body cells, further paving way to microfissures in the nasal mucosa during cold weather. Moreover cold depresses the ciliary movements in the respiratory tract, consequently increasing vulnerability to infections. ${ }^{28}$ A significant positive correlation was found between average relative humidity, mean monthly maximum and minimum temperatures and incidence of RSV in our study, even though the highest number of cases may not always coincide with the lowest temperature. In contrast, several authors have reported a negative correlation between temperature and incidence of $\mathrm{RSV},{ }^{11,12}$ while Passos et al. ${ }^{5}$ found a positive correlation between them.

The results of the real time RT-PCR assay presented here indicated its high performance compared to nRT-PCR. nRT-PCR was shown to detect significantly more numbers of RSV than tissue culture in a previous study. ${ }^{18}$ In India, studies by Nandhini et al. ${ }^{29}$ and Agrawal et al. ${ }^{12}$ reported that performance of real time RT-PCR in detecting RSV was greater than that of conventional RT-PCR, supporting the findings of our study.

\section{Conclusion}

The results obtained in the present study indicate high prevalence of RSV among children less than 5 years of age. The seasonality and climatic patterns of RSV infections closely resembled that in other parts of the country. Comparative analysis of real time RT-PCR and nRT-PCR further confirmed the increased sensitivity, specificity and rapidity of real time RT-PCR. The results demonstrate the significance of epidemiological surveillance of respiratory infections caused by RSV in South India. However, further studies with larger sample size are required to elucidate the absolute prevalence of RSV and associated risk factors.

\section{Conflicts of interest}

None of the authors have any conflicts of interest.

Table 4

Comparison of performance of nRT-PCR vs. Real time RT-PCR for the detection of respiratory syncytial virus.

\begin{tabular}{|c|c|c|c|c|c|c|c|}
\hline Real time RT-PCR & $\begin{array}{l}\text { nRT-PCR } \\
\text { negative }\end{array}$ & $\begin{array}{l}\text { nRT-PCR } \\
\text { positive }\end{array}$ & Sensitivity $\%(95 \% \mathrm{CI})^{\mathrm{a}}$ & Specificity \% (95\% CI) & $\mathrm{NLR}^{\mathrm{b}} \%(95 \% \mathrm{CI})$ & $\mathrm{NPV}^{\mathrm{c}} \%(95 \% \mathrm{CI})$ & $\begin{array}{l}\mathrm{PPV}^{\mathrm{d}} \%(95 \% \\
\mathrm{CI})\end{array}$ \\
\hline Negative & 114 & 0 & $21.88 \%(9.28 \%-39.97 \%)$ & $100 \%(96.82 \%-100 \%)$ & $0.78(0.65-0.94$ & $82.01 \%(7.15 \%-84.56 \%)$ & $100 \%$ \\
\hline Positive & 25 & 7 & & & & & \\
\hline $\mathrm{n}=146$ & 139 & 7 & & & & & \\
\hline
\end{tabular}

\footnotetext{
a CI- Confidence interval.

b NLR- Negative likelihood ratio.

c NPV- Negative predictive value.

d PPV- Positive predictive value.
} 


\section{Source of funding}

Intramural research funds, University of Madras, India.

\section{Acknowledgement}

None.

\section{References}

1. Anderson LJ, Parker RA, Strilms RL. Association between respiratory syncytial virus outbreaks and lower respiratory tract deaths of infants and young children. $J$ Infect Dis. 1990;161(4):640-646.

2. Falsey AR, Walsh EE. Respiratory syncytial virus infection in adults. Clin Microbiol Rev. 2000;13(3):371-384.

3. Walsh EE, McConnochie KM, Long CE, Hall CB. Severity of respiratory syncytial virus infection is related to virus strain. $J$ Infect Dis. 1997;175(4):814-820.

4. Collins PL, McIntosh K, Chanock M. Respiratory syncytial virus. In: Knipe DM, Howley PM, eds. BN Fields. Philadelphia: Virology; 1996:1313-1351.

5. Straliotto SM, Siqueira MM, Machado V, Maia TMR. Respiratory viruses in the pediatric intensive care unit: prevalence and clinical aspects. Mem Inst Oswaldo Cruz. 2004;99:883-887.

6. Passos SD, Gazeta RE, Felgueiras AP, Beneli PC, Coelho MD. Do pollution and climate influence respiratory tract infections in children? Rev Assoc Med Bras. 2014;60:276-282.

7. Lam WY, Yeung AC, Tang JW, et al. Rapid multiplex nested PCR for detection of respiratory viruses. J Clin Microbiol. 2007;45(11):3631-3640.

8. Mentel R, Wegner U, Bruns R, Gürtler L. Real-time PCR to improve the diagnosis of respiratory syncytial virus infection. J Med Microbiol. 2003;52(10):893-896.

9. Hamano-Hasegawa K, Morozumi M, Nakayama E, et al. Comprehensive detection of causative pathogens using real-time PCR to diagnose pediatric community-acquired pneumonia. J Infect Chemother. 2008;14(6):424-432

10. Bharaj P, Sullender WM, Kabra SK, et al. Respiratory viral infections detected by multiplex PCR among pediatric patients with lower respiratory tract infections seen at an urban hospital in Delhi from 2005 to 2007. Virol J. 2009;6(1):89.

11. Singh AK, Jain A, Jain B, et al. Viral aetiology of acute lower respiratory tract illness in hospitalised paediatric patients of a tertiary hospital: one year prospective study. Indian J Med Microbiol. 2014;32(1):13.

12. Agrawal AS, Sarkar M, Chakrabarti S, et al. Comparative evaluation of real-time PCR and conventional RT-PCR during a 2 year surveillance for influenza and respiratory syncytial virus among children with acute respiratory infections in Kolkata, India, reveals a distinct seasonality of infection. J Med Microbiol. 2009;58(12):1616-1622.

13. Choudhary ML, Anand SP, Wadhwa BS, Chadha MS. Genetic variability of human respiratory syncytial virus in Pune, Western India. Infect Genet Evol. 2013;20:369-377.

14. Babu BS, Gunasekaran P, Venkataraman P, Mohana S, Kiruba R, Ruban K. Prevalence and molecular characterization of circulating respiratory syncytial virus (RSV) in Chennai, south India during 2011-2014. Biosci Biotechnol Res Asia. 2016;13(2):1055-1062.

15. Bashir U, Nisar N, Mahmood N, Alam MM, Sadia H, Zaidi SS. Molecular detection and characterization of respiratory syncytial virus B genotypes circulating in Pakistani children. Infect Genet Evol. 2017;47:125-131.

16. Wang D, Chen L, Ding Y, et al. Viral etiology of medically attended influenza-like illnesses in children less than five years old in Suzhou, China, 2011-2014. J Med Virol. 2016;88(8):1334-1340.

17. Rowlinson E, Dueger E, Mansour A, et al. Incidence and etiology of hospitalized acute respiratory infections in the Egyptian Delta. Influenza Other Respir Viruses. 2017;11(1):23-32.

18. Zahran WA, Makled AF, Salama AA, El-Hendaw GR, Bader HS. Comparison of reverse transcription-PCR and viral culture for detection of respiratory syncytial virus in young children: relation to epidemiological and clinical findings. Egypt J Med Microbiol. 2017;26(2).

19. Yu X, Lu R, Wang Z, et al. Etiology and clinical characterization of respiratory virus infections in adult patients attending an emergency department in Beijing. PloS One. 2012;7(2):e32174.

20. Hall CB, Weinberg GA, Iwane MK, et al. The burden of respiratory syncytial virus infection in young children. N Engl J Med. 2009;360(6):588-598.

21. Fall A, Dia N, Kiori DE, et al. Epidemiology and molecular characterization of human respiratory syncytial virus in Senegal after four consecutive years of surveillance, 2012-2015. PloS One. 2016;11(6):e0157163.

22. Kattan RS. Molecular Epidemiology of Respiratory Syncytial Virus (RSV) in Southern Palestine.

23. Koetz A, Nilsson P, Lindén MV, Van Der Hoek L, Ripa T. Detection of human coronavirus NL63, human metapneumovirus and respiratory syncytial virus in children with respiratory tract infections in south-west Sweden. Clin Microbiol Infect. 2006;12(11):1089-1096.

24. Liu W, Chen D, Tan W, et al. Epidemiology and clinical presentations of respiratory syncytial virus subgroups A and B detected with multiplex real-time PCR. PloS One. 2016;11(10):e0165108.

25. Parveen S, Sullender WM, Fowler K, Lefkowitz EJ, Kapoor SK, Broor S. Genetic variability in the $\mathrm{G}$ protein gene of group A and B respiratory syncytial viruses from India. J Clin Virol. 2006;44(9):3055-3064.

26. Broberg E, Johansen K, Adlhoch C, Snacken R, Penttinen P. Seasonality of respiratory syncytial virus infection in the EU/EEA, 2010-2016. J Clin Virol. 2016;82:S116-S117

27. Tanner H, Boxall E, Osman H. Respiratory viral infections during the 2009-2010 winter season in Central England, UK: incidence and patterns of multiple virus coinfections. Eur J Clin Microbiol Infect Dis. 2012;31(11):3001-3006.

28. Tromp SW. Biometeorology-the Impact of the Weather and Climate on Humans and Their Environment (Animals and Plants). Heyden \& Son Ltd.; 1980.

29. Nandhini G, Sujatha S, Jain N, Dhodapkar R, Kadhiravan T, Krishnamurthy S. Poor performance characteristics of conventional PCR in detection of respiratory syncytia virus-experience of a tertiary care centre in Southern India. Indian J Med Microbiol. 2015;33(2):274 